\title{
JLEET
}

Journal of Language Education and Educational Technology

Volume 5, No. 2, 2020

e-ISSN: 2502-3306

\section{Teaching reading comprehension through task based language teaching}

\author{
Kamba Janna Mufabar, Hilaluddin Hanafi, Aderlaepe
}

Halu Oleo University, Indonesia. Email : kambajanna04@gmail.com

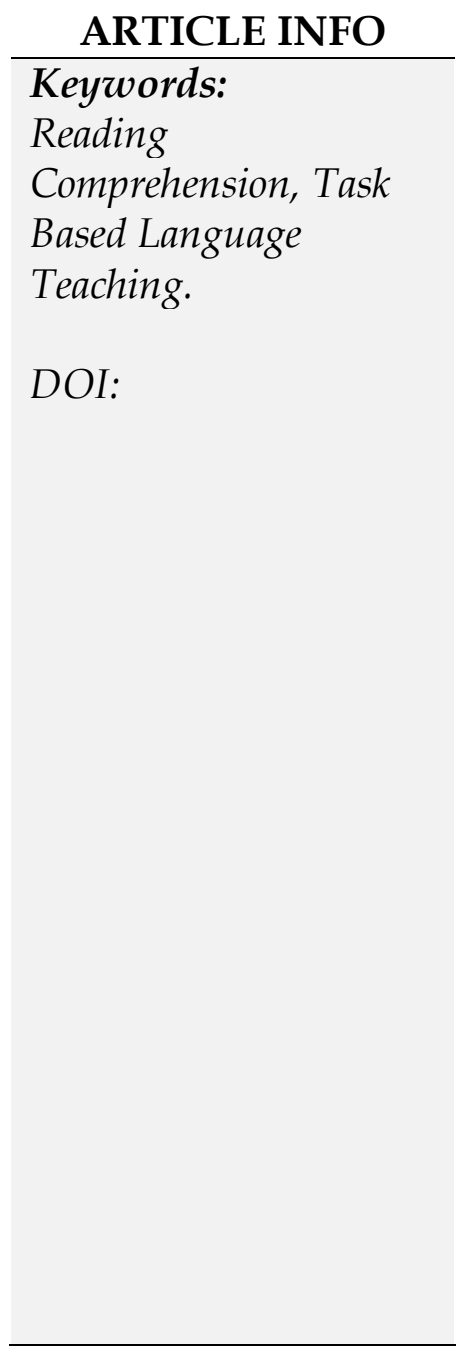

ABSTRACT

This study attempted to find out: (1) Whether the Task Based Language Teaching (TBLT) affects student reading comprehension or not, (2) The application of task based language teaching towards students' reading motivation. This study employed quasi experimental design to scrutinize the applicability of TBLT which involving $2^{\text {nd }}$ grade students of Junior High School 7 Kendari registered in academic year 2019/2020. To this end, 62 participants (including an experimental group and a control class) were selected through purposive sampling from among 180 students. Task Based Language Teaching was applied in teaching reading comprehension in experimental group while in control group ones was applied conventional. Both groups were taught the same topic. The test was administered before treatment (pretest) to examine the students' previous reading comprehension and it was then compared with their post-test to examine their reading comprehension after being taught using TBLT. Reading test and questionnaire as the instruments of this study. The data from reading test was used to figure out the students' reading comprehension by using t-test while the data from questionnaire was to figure out the students' reading motivation. All collected data were computed and analysed by using SPSS 24 . The results of 
reading comprehension test revealed that TBLT significantly effects students' reading comprehension. Moreover, the result of questionnaire displayed that the students became more motivated to read through Task Based Language Teaching (TBLT).

\section{INTRODUCTION}

Reading is one of a receptive skill in learning English language. Reading is including as one of the receptive skills in learning English language. As a receptive skill, it has a substantial contribution to students' internal knowledge. To assemble the information, students are required to attain the comprehension on reading. Reading comprehension is characterized as the level of understanding content. This understanding comes from the interaction between the words which are composed and how they trigger information exterior the content (Ellis in Mesbah \& Faghani, 2015:320). That's accepted that in learning English as a Foreign Language (EFL) setting, reading comprehension is the central implies for learning new information and it is the foremost fundamental ability required for the students' success in comprehending reading text. Reading comprehension is not simple to realize since one of the factor is the need of students' motivation. Reading motivation encompasses a considerable affect on reading comprehension (Hairul, Ahmadi, and Pourhosein in Ahmadi, 2017:2). One of the foremost vital variables which offer assistance learners examined more is reading motivation and it has a basic affect on reading comprehension.

With regard to the reading motivation as one of the figures which affects the students' reading comprehension, something required to be done. There are a few other conceivable ways in which the instructors may display reading comprehension materials. Hence, in this study the analyst will attempt to apply Task Based Language Teaching (TBLT) approach as one of the conceivable to overcome this issue to assist the students increase their reading comprehension. Task Based Language Teaching learners are primarily displayed with a task or issue to solve. There are three stages in Task Based Language Teaching; they are pre task, cycle task, and post task Willis \& Willis (1996:39). Subsequently, this approach is executed to move forward students' reading comprehension. Be that as it may, research on task based language teaching almost focuses on educating reading comprehension through task based language teaching in senior high and college students. Little research has been attempted to think about students' reading comprehension on junior high students'. Indeed in case, this approach has been actualized in junior high but the past analysts most focus on students' writing ability (Karim, Husain \& Weda, 2014; Rezaeyan, 2014; Panaveli, 2015; Tabrizi \& Hosseini, 2016) and grammar (Yildiz, 2017; Senel, 2017; Yijin \& Pham, 2017). In this research, the analyst would like to measure the students' reading comprehension by applying Task Based language Teaching. Based on above reasons, here are the research questions of this study: 
1. Is there any significant difference in reading comprehension between students who attend task based language teaching and conventional at SMPN 7 KDI?

2. What is students' reading motivation before and after attending task based language teaching?

\section{LITERATURE REVIEW}

\subsection{Reading Comprehension}

Raising students' mindfulness of primary thoughts in a content and investigating the organization of a content are basic for good comprehension. Comprehension is the method of determining meaning from associated content. It includes word information (lexicon) as well as considering and thinking. The reader effectively locks in with the content to build meaning. This dynamic engagement incorporates making utilize of earlier information. It includes drawing deductions from the words and expressions that a writer employments to communicate information, ideas and perspectives. Allen, Hendler, Tate in Rezaei, Mehri, and Shakerian (2017) pointed out that comprehension could be a process by which new or approaching information is related to the information that's already put away in memory. Comes with Cook in Rezaei, Mehri, and Shakerian (2017) said that comprehension entirely depends on the putting away and processing of information by our minds. Subsequently, comprehension is something mentalistic. In less difficult terms, comprehension is the method by which a individual gets it the meaning of composed or spoken language.

Besides, reading comprehension may be a reader's activities which interact to writer through written content which include a synchronous process of comprehending, understanding and getting information. Reading comprehension is the method of extricating and building meaning through interaction and involvement with written language at the same time. Ellis in Mesbah and Faghani (2015) characterized that reading comprehension is as the level of understanding of content. This understanding comes from the interaction between the words that are written and how they trigger information exterior the content. It is accepted that in learning English as a Foreign Language (EFL) settings, reading comprehension is the central means for learning modern information and it is the foremost critical ability required for the students' success in reading comprehension.

\subsection{Concept of Task}

Motlagh, Jafari, and Yazdani (2014:1) argued that task is any action which is outlined to assist the accomplishment of a specific learning objective. In other words, task is an activity with an outcome. In order to perform a task, learners must go through prepare of thought which is observed and organized by instructors. In any case, it must be specified that tasks and exercises are different. Besides, Richard and Bren in Rezaeyan (2014:477) declared that task is an action such as listening a few commands or the tape, drawing a few tables that is done as the result of processing and understanding the language. By doing the task it implies the students do a process and understanding the language since task is done as the result both of them. To make a communicative teaching language the teacher ought to educate the students in different task. Agreeing to Richard, Platt, and 
Wegber as cited in Rezaeyan (2014:477) that language teaching can be more communicative by utilizing different task.

\subsection{Task Based Language Teaching}

Task Based Instruction (TBI) is additionally called Task Based Approach (TBA) or Task Based Language Teaching (TBLT). Task based language teaching could be a teaching approach which is based on the utilization of communicative and interactive tasks in order to plan and convey instruction. Task based approach center on communicative and cognitive forms. The students are able to create their language aptitudes normally by communicate with others around the task that they carry out (Demirel and Amer, 2017:124). Prabhu in Madhkhan and Mousavi (2017:119) designed task based teaching and learning tasks based on the concept that compelling learning occurs when students are completely engaged in a language task, instead of fair learning around language. Willis in Madhkhan and Mousavi (2017:119) characterized task as an goal oriented action which can have a clear purpose and which includes accomplishing an outcome through making a last product that can be appreciated by others.

In other words, TBLT refers to an approach based on the center unit of planning and instruction in language instructing (Richard \&Rodgers in Irfan, 2017:114). It sees the learning process as set of communicative tasks that are straightforwardly connected to the curricular objectives. This implies that within the implementation of TBLT learners are as a rule displayed with a task. Willis \& Willis (1996:39) clarified the three stages of the procedure of teaching by utilizing TBLT, they are: pre task, cycle task and post task. In this manner, in actualizing this approach there will be these three of stages.

\subsection{Motivation}

The theory of Self-Determination Theory (SDT; Deci \& Ryan 1985) distinguished between different types of motivation based on the different reasons or goals that give rise to an action. The most basic distinction is between intrinsic motivation and extrinsic motivation.

\subsubsection{Intrinsic Motivation}

According to Ryan and Decci in Ahmadi, Ismail, and Abdullah (2013:11) that intrinsic motivation is as inner desire and internal needs such as students would study more if they have an individual interest in what they are learning about and are allowed to choose their own courses of actions. Furthermore, the freedom to choose courses of actions improves learning abilities and intrinsic motivation as explained by the psychologists, that at the beginning of time in some different circumstances without any reward because they are allowed to do the actions they desire to do over and over. Intrinsic motivation has more impact than other factors to positively affect human because it elaborates inner interests, abilities, adaptations, and indications that are fundamental to the social and cognitive development.

Intrinsic motivation refers to behavior that is driven by internal reward. In other words, the motivation to engage in a behavior arises from within the individual because it is intrinsically rewarding (Alberth, 2018). Intrinsic motivation occurs when we act without 
any obvious external rewards. We simply enjoy an activity or see it as an opportunity to explore, learn, and actualize our potential. Intrinsic motivation refers to the reason why we perform certain activities for inherent satisfaction or pleasure; one might perform one of these activities in reinforcing in-and-of-itself (Hairul, Ahmadi, and Pourhossein in Ahmadi, Ismail, and Abdullah (2013:11).

\subsubsection{Extrinsic Motivation}

Extrinsic motivation relates to the reward an individual will get as a result of any instrumental actions. Thus it does not basically refer to determination in the activities or behavior. The extrinsic motivational factors need to be categorized in the area of the interest. It refers to the motivation that comes from outside rewards such as money or grades. The motivation comes from the pleasure one gets from the task itself or from the sense of satisfaction in completing or even working on a task.

Hairul, Ahmadi and Pourhossein in Ahmadi, Ismail, and Abdullah (2013:11) stated that extrinsic motivation is a construct that pertains whenever an activity is done in order to attain some separable outcome. Extrinsic motivation is thus contrast with intrinsic motivation, which refers to doing an activity simply for the enjoyment of the activity itself, rather than its instrumental value. However, unlike some perspectives that view extrinsically motivated behavior as invariantly non-autonomous, proposes that extrinsic motivation can vary greatly in the degree to which it is non-autonomous. For example, a student who does his/her homework only because he/she fears parental sanction for not doing it is extrinsically motivated because he/she is doing the work in order to attain the separable outcome of avoiding sanctions. Similarly, a student who does the work because he/she personally believes it is valuable for her chosen career is also extrinsically motivated because he/she too is doing it for its instrumental value rather than because she finds it interesting. Both examples involve instrumentalities, yet the latter case entails personal endorsement and a feeling of choice, whereas the former involves mere compliance with an external control. Both represent intentional behavior, but the two types of extrinsic motivation vary in their relative autonomy.

\subsection{Reading Motivation}

Grabe and Stoller in Ahmadi (2011) stated that reading motivation is very important for learners and it increases learners' reading comprehension and has great impact on reading comprehension (Hairul, Ahmadi, and Pourhosein, 2012). It is important for learners to read and understand texts easily and effectively. Therefore, all EFL learners need to improve their reading motivation for a better understanding of written text.

Furthermore, Motivation is one factor that affects students' reading comprehension activities (Seymour and Walsh in Ahmadi, 2017). While it has a significant role in language learning, it is equally important in reading comprehension. Reading motivation helps EFL learners read more efficiently. This also has been supported by Wang, Rosenfeld, Leung, and Oltman in Ahmadi (2017) who emphasized that learners who learn a foreign language should develop their reading ability for the better comprehension of written texts and it has relation with reading motivation that it is very important for learners and it increases 
learners' reading comprehension. Therefore, many investigators have been well aware of the significance of motivation in the target language learning and how motivation increases comprehension among language learners.

In addition, reading motivation as one's own purpose, idea and desire related to the title, action and results of the reading. According to Hairul, Ahmadi and Pourssein (2012) interpreted that reading motivation as the large amount of motivation that learners have to determine their positive or negative opinions about reading. For example, students who read for pleasure and employing strategies to support their comprehension are highly motivated readers. If it so, the learners are consider reading to be an important factor in their daily activities, accept challenges in the reading process and are likely to be successful readers.

\section{METHODS}

This study used quantitative design to study about teaching reading comprehension through task based language teaching. The population of this study was the second grade of Junior High School 7 Kendari academic year 2019/2020. The technique of taking sample in this study was purposive sampling and the researcher took 2 classes (VIII A and VIII B) as experiment class and control class. The researcher conducted this study from late February to middle March 2020. The data are collected by giving reading test and closeended questionnaire of reading motivation. In order to analyze the data, the researcher took some steps below:

1. First, the researcher gave score to students' answer in reading test based on marking scheme.

2. Second, the researcher calculated the frequency and percentage of each answer by using Microsoft Excel. Then, find out the minimal, maximum, mean score and standard deviation.

3. Third, the researcher executed a normality test both of the experiment and control classes by using SPSS 24.

4. Fourth, the researcher did a homogeneity test next to analyse the hypothesis test through SPSS 24.

5. Last, the researcher analysed the questionnaire of students' reading motivation answer. The researcher gave score for each student answer and write down the frequency and percentage of each answer by using Microsoft Excel.

6. Second, the researcher wrote some important notes and conclusion after observing how each teacher teach and in English Class 


\section{FINDINGS AND DISCUSSION}

\subsection{Findings}

This section is divided into two sections: Result of reading test and reading motivation questionnaire.

\section{Result of Reading Test}

After the data were gathered, descriptive statistics applied to know the significant differences between students' reading comprehension of experimental and control group. Students' score of the experimental and control group on the pre-test and post-test were provided using Microsoft Excel and SPSS 24. See tables below.

Table 1 Students' Score on Pre-Test and Post Test in Experiment Class

\begin{tabular}{|c|c|c|c|c|c|c|}
\hline \multicolumn{4}{|c|}{ Pre Test } & \multicolumn{3}{|c|}{ Post Test } \\
\hline No & Score & Frequency & Percentage $\%$ & Score & $\begin{array}{c}\text { Frequenc } \\
y\end{array}$ & $\begin{array}{c}\text { Percentage } \\
\%\end{array}$ \\
\hline 1 & 22.2 & 1 & 3.2 & 30.5 & 1 & 3.2 \\
\hline 2 & 33.3 & 1 & 3.2 & 38.8 & 1 & 3.2 \\
\hline 3 & 41.6 & 2 & 6.5 & 47.2 & 4 & 12.9 \\
\hline 4 & 44.4 & 3 & 9.7 & 50 & 1 & 3.2 \\
\hline 5 & 47.2 & 2 & 6.5 & 55.5 & 4 & 12.9 \\
\hline 6 & 50 & 2 & 6.5 & 58.3 & 2 & 6.5 \\
\hline 7 & 55.5 & 4 & 12.9 & 63.8 & 1 & 3.2 \\
\hline 8 & 58.3 & 2 & 6.5 & 66.6 & 6 & 19.5 \\
\hline 9 & 61.1 & 1 & 3.2 & 72.2 & 1 & 3.2 \\
\hline 10 & 63.8 & 4 & 12.9 & 75 & 3 & 9.7 \\
\hline 11 & 66.6 & 1 & 3.2 & 77.7 & 5 & 16.1 \\
\hline 12 & 69.4 & 4 & 12.9 & 80.5 & 1 & 3.2 \\
\hline 13 & 72.2 & 3 & 9.7 & 86.1 & 1 & 3.2 \\
\hline \multirow{6}{*}{14} & 75 & 1 & 3.2 & & & \\
\hline & TOTAL & 31 & 100 & TOTAL & 31 & 100 \\
\hline & Mean & \multicolumn{2}{|l|}{56.67} & Mean & \multicolumn{2}{|l|}{63.30} \\
\hline & SD & \multicolumn{2}{|l|}{12,84348628} & SD & \multicolumn{2}{|c|}{13,65177605} \\
\hline & Minimum & \multicolumn{2}{|l|}{22.2} & Minimum & \multicolumn{2}{|c|}{30.5} \\
\hline & Maximum & \multicolumn{2}{|l|}{75} & Maximum & \multicolumn{2}{|l|}{86.1} \\
\hline
\end{tabular}

The above table shows the students' score on pre-test and post-test in experiment class. Based on the table there are two kinds of score, before and after teaching reading comprehension through task based language teaching. There is an increasing score, frequency and percentage from pre-test to post-test. It also shows the mean score of pretest is categorized in "average" criteria while post-test mean score is including in "high" criteria. 
Table 2. Students' Score on Pre-Test and Post Test for Control Class

\begin{tabular}{|c|c|c|c|c|c|c|}
\hline \multicolumn{4}{|c|}{ Pre Test } & \multicolumn{3}{|c|}{ Post Test } \\
\hline No & Score & Frequency & Percentage $\%$ & Score & Frequency & Percentage $\%$ \\
\hline 1 & 22.2 & 2 & 6.5 & 25 & 1 & 3.2 \\
\hline 2 & 30.5 & 1 & 3.2 & 30.5 & 1 & 3.2 \\
\hline 3 & 41.6 & 3 & 9.7 & 33.3 & 1 & 3.2 \\
\hline 4 & 44.4 & 3 & 9.7 & 41.6 & 3 & 9.7 \\
\hline 5 & 47.2 & 2 & 6.5 & 47.2 & 2 & 6.5 \\
\hline 6 & 50 & 3 & 9.7 & 50 & 5 & 16.1 \\
\hline 7 & 52.7 & 1 & 3.2 & 52.7 & 2 & 6.5 \\
\hline 8 & 55.5 & 1 & 3.2 & 55.5 & 1 & 3.2 \\
\hline 9 & 58.3 & 1 & 3.2 & 58.3 & 1 & 3.2 \\
\hline 10 & 61.1 & 4 & 12.9 & 63.8 & 1 & 3.2 \\
\hline 11 & 63.8 & 3 & 9.7 & 66.6 & 5 & 16.1 \\
\hline 12 & 72.2 & 4 & 12.9 & 69.4 & 1 & 3.2 \\
\hline 13 & 75 & 3 & 9.7 & 72.2 & 1 & 3.2 \\
\hline 14 & & & & 75 & 3 & 9.7 \\
\hline 15 & & & & 77.7 & 3 & 9.7 \\
\hline \multicolumn{2}{|c|}{ TOTAL } & 31 & 100 & & 31 & 100 \\
\hline \multicolumn{2}{|c|}{ Mean } & \multicolumn{3}{|l|}{54.62} & Mean & 57.21 \\
\hline \multicolumn{2}{|c|}{ SD } & \multicolumn{3}{|l|}{14.8334974} & SD & 14.86077828 \\
\hline \multicolumn{2}{|c|}{ Minimum } & \multicolumn{3}{|l|}{22.2} & Minimum & 25 \\
\hline \multicolumn{2}{|c|}{ Maximum } & 75 & & & Maximum & 77.7 \\
\hline
\end{tabular}

The above table illustrates the students' score on pre-test and post-test in control class. Based on the table there are two kinds of score, before and after teaching reading comprehension conventionally. There is an increasing score, frequency and percentage from pre-test to post-test. However, the mean score of pre-test and post-test in control class are categorized in "average" criteria. 
Table 3. Independent Sample T-Test

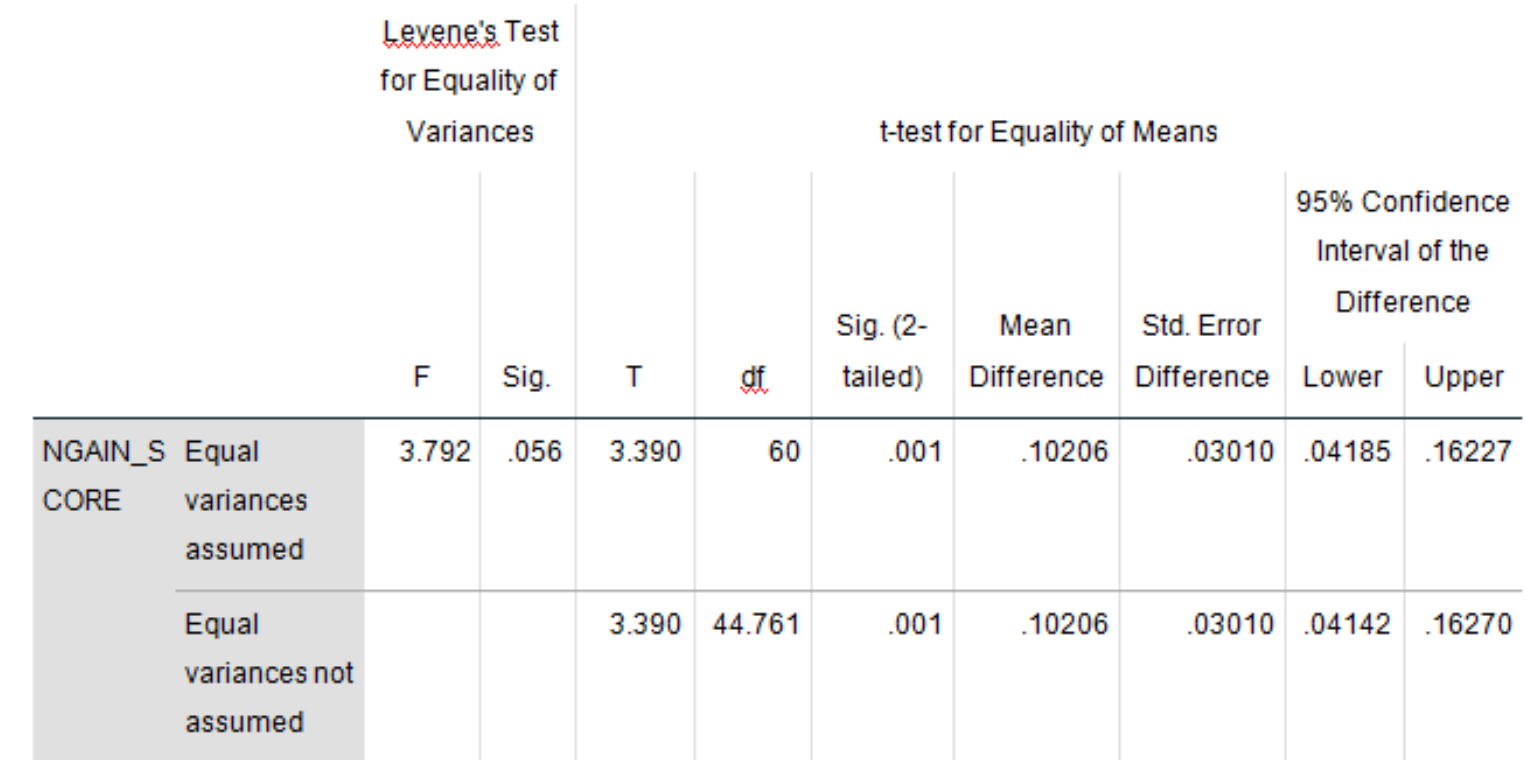

The table describes the independent sample t-test. In that independent $t$-test SPSS output can be seen in the level of significant is $0.001, p<0.05$. Furthermore, it figures out that H1 is accepted, means that teaching reading comprehension through task based language teaching is more effective than teaching reading comprehension conventionally.

\section{Result of Reading Motivation}

After taking the result of reading motivation questionnaire, the researcher recaps the data of students' motivation in experimental class before and after giving the treatment. See the table below.

\section{Table 4. Recapitulation Data of Students' Motivation in Experimental Class (Pretest)}

\begin{tabular}{|c|c|c|c|}
\hline Questionnaires & Total Score & Percentage Level & Criteria \\
\hline 1 & 64 & 42.66 & Moderate \\
\hline 2 & 62 & 41.33 & Moderate \\
\hline 3 & 60 & 40.00 & Moderate \\
\hline 4 & 70 & 46.66 & Moderate \\
\hline 5 & 67 & 44.66 & Moderate \\
\hline 6 & 55 & 36.66 & Low \\
\hline 7 & 122 & 81.33 & Very high \\
\hline 8 & 123 & 82.00 & Very high \\
\hline 9 & 125 & 83.33 & Very high \\
\hline 10 & 53 & 35.33 & Low \\
\hline Total & $\mathbf{8 0 1}$ & $\mathbf{5 3 3 . 9 6}$ & Moderate \\
\hline Average of motivation level
\end{tabular}

The above table illustrates that recapitulation data of students' motivation in experimental class (Pretest). Based on the table there are 10 items of reading motivation questionnaire. Among of them 
there are some criteria (very high, moderate, and low). Items of questionnaire number 7, 9 and 10 are categorized "very high" level. Then, items number 1, 2, 3, 4, and 5 are categorized "moderate". While, items 6 and 10 are "low" categorize. It means before the teacher apply task based language teaching approach the average of reading motivation is $53.39 \%$ which is categorized "moderate" level.

Table 5 Recapitulation Data of Students' Motivation in Experimental Class (Posttest)

\begin{tabular}{|c|c|c|c|}
\hline Questionnaires & Total Score & Percentage Level & Criteria \\
\hline 1 & 127 & 84.66 & Very high \\
\hline 2 & 124 & 82.66 & Very high \\
\hline 3 & 125 & 83.33 & Very high \\
\hline 4 & 125 & 83.33 & Very high \\
\hline 5 & 125 & 83.33 & Very high \\
\hline 6 & 123 & 82.00 & Low \\
\hline 7 & 56 & 37.33 & Low \\
\hline 8 & 54 & 36.00 & Very high \\
\hline 9 & 53 & 35.33 & High \\
\hline 10 & 124 & 82.66 & \\
\hline Total & 1036 & & \\
\hline Average of motivation level & & & \\
\hline
\end{tabular}

The above table presents that recapitulation data of students' motivation in experimental class (Posttest). Based on the table there are 10 items of reading motivation questionnaire. Among of them there are some criteria (very high and low). Items of questionnaire number 1,2,3,4,5,6, and 10 are including in "very high" level while items number 7,8 and 9 are categorized "low" level in reading motivation. It means after the teacher applying task based language teaching approach in the classroom especially in reading the average of reading motivation is $69.06 \%$ which is categorized "high" level.

\subsection{Discussion}

This research was conducted to investigate whether there is a significant effect of applying task based language teaching approach and to find out students' reading motivation before and after attending task based language teaching on eight class of SMP Negeri 7 Kendari. The result was proven by the output of SPSS data processing. It began with the descriptive analysis (minimum, maximum, mean, and standard deviation) both experiment and control classes score. Then, analyze the normality, homogeneity, and ended by the judgments the accepted hypothesis. Finally, the researcher found that there 
is a significant effect of applying task based language teaching approach on students' reading comprehension.

The finding of this research are compatible with what the experts said about the advantages of task based language teaching approach on students' reading comprehension. The students can be facilitated by using TBLT which the materials focus on meaning. Second, during the interaction in the classroom, TBLT can demonstrate the language acquisition. Third, TBLT involves four skills: speaking, listening, reading and writing. In addition, Ellis in Hismanoglu and Hismanoglu (2011:49) listed some benefits of using TBLT. First, TBLT focus on students center but the teacher still has a role to guide, monitor, and facilitator for the students.

In this research, there were four meetings used to give treatments to experiment class. Another class (control class) was not taught by using task based language teaching approach but conventionally. In experiment class, in every meeting, there was a worksheet for students. Thus, during four meetings, four worksheets selected and a worksheet was spread every meeting. A worksheet consists of the text of recount text. The text was taken in two resources. First, English text book by Wardiman, A., Masduki B Jahur., \& M. Sukirman Djusma. (2008). English in Focus: for Grade VIII Junior High School (SMP/MTS). Pusat Perbukuan, Departemen Pendidikan Nasional. Second, English text book by Nur Zaida. Bright an English Course for Junior High School Students. Erlangga (2008).

The main difference between experiment class and the control class was the existence of task based language teaching approach in every meeting. Both of class basically was the same, the teaching of recount text. In experiment class taught in TBLT means taught by applying three stages of tasks (pre task, cycle task and post task) in every meeting. Every stage of task has different activities in the classroom. It cause different responses from the students. It related to the atmosphere of the class related to their impression about the class. After being compared, class that taught in TBLT was better and more effective for the students than conventionally.

Furthermore, the quantitative result of this research showed the effect of task based language teaching approach in those two different class. Students' reading comprehension before treatment can be seen in their pretest mean score, that is, 56.67 and the pretest of control class is 54.62. After applying task based language teaching approach in experiment class the mean score was 63.30 while conventionally in control class the posttest was 57.21. It showed that there was an effect of task based language teaching approach on students' reading comprehension.

In addition, the researcher analyzed the students' reading motivation questionnaire by using Likert Scale. The researcher gave the questionnaire in experiment class before and after giving treatment. The researcher used this questionnaire to find out whether the task based language teaching approach can effect students' reading motivation or not. There were 10 items of questionnaire. They consisted of 7 positive statements and 3 negative statement. The researcher analyzed them by using Microsoft Excel. The result showed that on pretest experiment class the average of motivation level was $53.39 \%$ and it 
was categorized "moderate" level. While the percentage on posttest was $69.06 \%$ or it has "high" motivation level.

Through this finding, obviously, task based approach can be integrated in English teaching even in reading comprehension, not only for English students in overseas but also students who learn English as their foreign language, one of the real model was students eighth class of SMP Negeri 7 Kendari. It was noted that there was a difference between students experiment class and control class after giving of treatment by using task based language teaching approach. Students in control class the teacher taught conventionally was not comprehend students well as students in experiment class that most of them did not get involved well in learning process. It is because there was no variation in their classroom. The class was monotonous and quite rigid. Most of them looked bored so the teacher had to guide them to focus on the learning process hardly. While students in experiment class showed different response that most of them got involved well in learning process, were motivated and so interested in teaching and learning process and whole integrated phases in the approach. They were easier to guide to the learning process. The class atmosphere was very different with experiment classroom that most of the students felt excited.

In conclusion, task based language approach is one of an approach that can increase students' reading comprehension and students' reading motivation particularly in reading recount text. It can be proved quantitatively that students' comprehend was increased by looking statistic data that have been presented in the previous pages.

\section{CONCLUSION}

After conducting the research and analyzing the data, finally it can be concluded that there was a significant effect of task based language teaching approach on students' reading comprehension and motivation at eighth class of SMP Negeri 7 Kendari. It was showed by the mean score of pretest and posttest both of class.

The data showed that in the pretest of experiment class showed that 56.67 while posttest in experiment class was 63.30. Compared to mean score of control class on pretest was 54.62 and 57.21 on posttest. It means there was any significant effect before and after treatment in experiment class by seeing the pre and posttest while in control class also has any significant effect after the teacher taught them conventionally. However, if comparing the mean score both of the class, experiment class has higher interval from pretest to posttest than interval from pretest to posttest of control class. The interval from pretest to posttest of experiment class was 6.63 while in control class was 2.59 .

In addition, the data was also supported by the hypothesis testing that the value of significance $p, 0.001<0,05$, means that there was a significant effect of the use of task based language approach on students' reading comprehension. Then, task based language teaching approach was effective to attact students' attention in teaching reading comprehension especially recount text. Besides that, the students' reading motivation before and after giving the treatment also showed that there is any significant improvement. The result showed that on pretest experiment class the average of motivation level was $53.39 \%$ and it was categorized "moderate" level. While the 
percentage on posttest was $69.06 \%$ or it has "high" motivation level. Moreover, the students' score and students' reading motivation showed how the statement was proved quantitatively.

\section{References}

Ahmadi. M. R., Ismail. H. N., \& Abdullah. N. K. K. (2013). The Relationship Between Students' Reading Motivation and Reading Comprehension. Journal of Education and Practice 18 (4), 8-17.

Alberth. (2018). Indonesian high school student motivational orientations for learning English as a foreign language: Some preliminary findings. Electronic Journal of Foreign Language Teaching, 15(2), 304-321. Retrieved from http:/ / e-flt.nus.edu.sg/

Astuti. R.T. (2018). Improving Students' Reading Comprehension Ability Using Task Based Language Teaching at MTs Negeri 1 Yogyakarta. Jurnal Pendidikan Madrasah, 3 (2), 279-290.

Dakhi. S., \& Damanik. I.S. (2018). Students' Motivation in Reading English Text: A Qualitative Study in EFL Context. Journal of English Teaching, 2 (4), 81-93.

Demirel. O., \& Amer. A. B. (2017). The Effect of Task-Based Language Teaching (TBLT) on the Reading Comprehension in EFL Classes. Education and Linguistics Research, 2 (3), 123-130.

Ferdila. R. (2014). The Use of Extensive Reading in Teaching Reading. Journal of English and Education, 2 (2), 68-80.

Fisher. A. S. H. (2016). Students' Reading Techniques Difficulties in Recount Text. Journal of English and Education, 4 (2), 1-12.

Golchin. V. F., \& Kheirabadi. M.D. (2013). Enhancing Reading Comprehension of Iranian Advanced EFL Learners through Task-based Reading Activities. International Journal of Applied Linguistics E English Literature, 2 (5), 62-69.

Hismanoglu, M., \& Hismanoglu, S. (2011). Task-Based Language Teaching; what every EFL Teacher should do. Procedia Social and Behavioural Sciences, 46-52.

Irfan. (2017). The Effect of Task-Based Language Teaching on Students' Reading Comprehention. English Education Journal (EEJ), 8(1), 113-126.

Jones, M.G., \& Araje, L.B. (2002). The Impact of Constructivism on Education: Language, Discourse, and Meaning. American Communication Journal, 5(3).

Kumara. G.D.G.A., Padmadewi. N.N., \& Suawarnajaya. I.W. (2013) The Effect of

Task Based Language Teaching and English Grammar Mastery toward Rading Comprehension of the Second Semester Students.E-Journal Program Pascasarjana Universitas Pendidikan Ganesha, 1.

Kusdemir. Y., \& Bulut. P. (2018). The Relationship between Elementary School

Students' Reading Comprehension and Reading Motivation. Journal of Education and Training Studies, 12 (6), 97-110.

Madhkhan. M., \& Mousavi. S.M. (2017). The Effect of Implimentation of TBLT in

Reading Comprehension Classes of Iranian EFL Learners. English Language Teaching; 10 (11), 119-128. 
Mesbah. M. (2016). Task-based Language Teaching and Its Effect on Medical Students' Reading Comprehension. Theory and Practice in Language Studies, 6 (2), 431438.

Mesbah. M., \& Faghani. M. (2015). Task-based and Grammar Translation Teaching Methods in TeachingReading Comprehension to nursing students: An Action Research. Aula Orientalis, 1, 319-325.

Motlagh. F. A., Jafari. A. S., \& Yazdani. Z. (2014). A general Overview of TaskBased Language Teaching (TBLT) from Theory to Practice. International Journal of Language and Linguistics, 2 (5-1), 1-11.

Mubarok. H., \& Sofiana. N. (2017). The Effect of Task-Based Language

Learning and Learning Styles on the Students' Reading Ability.Journal of Language and Literature, 12 (1), 19-29.

Ngussa, B.M., \&Makawe, L.N. (2014). Constructivism Experiences in Teaching-Learning Transaction among Adventist Secondary School in South Nyanza, Tanzania. American Journal of Educational Research 2(11A), 1-7.

Poupore. G. (2014). The Influence of Content on Adult L2 Learners' Task

Motivation: An Interest Theory Perspective. The Canadian Journal of Applied Linguistics, 17, (2), 69-90.

Rahi, S. (2017). Researche Design and Methods: A Systematic Review of Research Paradigms, Sampling Issues, and Instruments Development. International Journal of Economics \& Management Sciences, 6(2), 1-5.

Rezaei. O., Mehri. M., \& Shakerian. P. (2017). The Effect of the Implementation of Task Based LanguageTeaching on Iranian EFL Learners' Reading Comprehension. Journal of Applied Linguistics and Language Research, 4 (7), 247-259.

Rezaeyan, M. (2014). On The Impact of Task-Based Teaching on Academic Achievement of Iranian of EFL Learners (Case Study: Female High School Students in Yasuj). International Journal of Language Learning and Apply Linguistics World (IJLLALW), 7(3), 476-493.

Setayesh. M., \& Marzban. A. (2017). The Impact of Task-Based Language

Teaching on the Development of Iranian EFL Learners' ESP Reading Comprehension Skills. Advances in Language and Literary Studies, 8 (2), 70-76. 